\title{
Temanummer om «etikkbolgen» i yrkesutdanning og -praksis
}

\section{Leder}

\author{
Siri Granum Carson og May Thorseth
}

Dersom ein profesjon er ei samanslutning med eit samfunnsoppdrag og det samfunnsoppdraget krev at dei som har fått oppdraget held eigeninteresser i sjakk, er ein profesjon og ein mekanisme for kontroll av eigeninteresser. Som slik er han då også ein mekanisme for instituisjonalisert [sic] intern mistillit. Det er profesjonen som bærar av det moralske ansvaret og som eigen internkontrollør som må halde styr på utøvarane sine eigeninteresser. (Grimen 2006)

Høstens utgave av Etikk i praksis er et temanummer om «etikkbølgen» innen yrkesutdanning og -praksis, altså tendensen til å gjøre etikk til et eksplisitt tema for fag, kurs, kodekser og retningslinjer innen ulike profesjoner og utdanningsløp. Den tematiske delen består av fire artikler som omhandler ulike yrkesgruppers møte med «etikkbølgen». I den åpne delen har vi to artikler: en som drøfter vårens store profesjonsetiske slag i norsk politikk, nemlig fastlegenes reservasjonsrett, og en som tar for seg en ofte oversett side ved global rettferdighet, nemlig de fattige landenes forpliktelser.

Etikk har i stadig større grad blitt en eksplisitt del av yrkesutdanningene. Mens yrkesetiske verdier tidligere ble ansett som noe som yrkesutøvere nærmest umerkelig ble sosialisert inn i gjennom utdanning og praksis, vokser etikk i dag frem som et eget fag i mange utdanninger. Blant økonomisk-administrative utdanninger har det for eksempel frem til nylig vært svært variabelt i hvilken grad etikk ble gjort til tema, og i hvilken grad det dreide seg om valgfag eller obligatoriske kurs. I 2012 bestemte imidlertid NRØA (Nasjonalt råd for økonomisk-administrativ utdanning, et av fem nasjonale råd under Universitets- og høgskolerådet) at alle norske bachelorutdanninger i økonomi og administrasjon skal ha fem studiepoeng i etikk i rammeplanen. Ropet etter mer etikk kommer fra mange hold. Da pensum på examen philosophicum ved NTNU nylig ble revidert, etterspurte sivilingeniørstudentene mer vekt på etikk og fikk gjennomslag for dette.

Samtidig formulerer stadig flere yrkesgrupper et sett med etiske retningslinjer som skal gjelde spesielt for yrkesgruppen. I 2012 fikk også norske lærere og førskoleansatte sine første felles etiske retningslinjer da Utdanningsforbundet vedtok «Lærerprofesjonens etiske plattform». Formuleringen av yrkesetiske retningslinjer aktualiserer spørsmål knyttet til ulike yrkesgruppers legitimitet og selvstendighet, og omgivelsenes tillit til at disse gruppene forvalter sitt samfunnsoppdrag på en god måte. Det bringer også opp spørsmålet om hvorvidt ivaretagelsen av yrkesgruppens samfunnsoppdrag i visse tilfeller kan komme i konflikt med samfunnets overordnede verdier, eller den såkalte allmennmoralen. Hvor kommer presset om mer etikk i utdanningen og eksplisitt formulerte 
etiske retningslinjer fra? Og hva er det godt for? Er fokuset på etikk i yrkeslivet bare bra, eller kan det også ha uønskede virkninger?

Den første artikkelen - «Professionernes etiske kerne» av Morten Dige - tar nettopp for seg mulige problemer knyttet til «etikkbølgen», slik den utspiller seg for de klassiske hjelpeprofesjonene. Dige argumenterer for at hjelpeprofesjonene utpeker seg ved å være etiske $i$ sin kjerne, det vil si at de har som primært formål å verne om og fremme bestemte etiske grunnverdier. Med utgangspunkt i en konkret case fra dansk barnevern forsøker Dige å vise hvordan forståelsen av etiske verdier som identitetskonstituerende for profesjonene kommer under press fra det målrasjonelle organisasjonsparadigmet («New Public Management»), hvor formuleringen av etiske verdier snarere spiller en rolle som ytre, regulerende instans.

Den neste artikkelen - «Lärares yrkesetiska dilemman och den ökande juridifieringen i Sverige» av Gunnel Colnerud - dreier seg om en annen problematisk side ved «etikkbølgen», nemlig at den kan utvikle seg i retning av en juridifisering av yrkeslivet. Colnerud tar utgangspunkt i fremveksten av etiske retningslinjer for læreryrket i Sverige og den dydsetiske kritikken mot regeletikk som fulgte i kjølvannet av denne. Ifølge empiriske studier opplever svenske lærere plikten til å gripe inn mot en kollega som handler etisk klanderverdig overfor elever, som et utfordrende etisk dilemma. Plikten ble fastslått i de svenske lærernes etiske retningslinjer fra 2001 og ble i 2008 nedfelt i den svenske Skollagen, med den konsekvens at lærerne i dag er juridisk pålagt å anmelde brudd på retningslinjene. Colnerud peker på mulige uheldige konsekvenser av juridifiseringen - eksempelvis at det oppstår en «anmeldelsesfrykt» som gjør at man unnlater å gripe inn i vanskelige situasjoner.

Tredje bidrag er «Etisk kompetanseheving i norske kommuner - hva er gjort, og hva har vært levedyktig over tid?» av Elisabeth Gjerberg, Lillian Lillemoen, Anne Dreyer, Reidar Pedersen og Reidun Førde. Her får vi presentert en empirisk undersøkelse av hvordan «etikkbølgen» utspiller seg i norske kommuner, i form av resultatene fra en evaluering av prosjektet «Samarbeid om etisk kompetanseheving i kommunene». Dette ambisiøse og omfattende prosjektet startet i 2007 og skal avsluttes i 2015, og formålet er å styrke den etiske kompetansen i kommunenes helse-, sosial- og omsorgstjenester og stimulere til etikkrefleksjon i praksis. Evalueringen viser stor variasjon mellom de ulike kommunene, både i måten etikkarbeidet forankres på, og i hvor stor grad satsingen følges opp over tid. Artikkelen diskuterer utfordringer knyttet til kunnskapsoverføring, og Gjerberg et al. peker på at gode metoder og forankring hos ledelse og ansatte er viktige forutsetninger for å etablere og vedlikeholde etikkrefleksjon som en naturlig del av praksis.

I den fjerde og siste artikkelen i tematisk del - «'Dic cur hic' - en kasuistisk forskningsetik» av Martin Blok Johansen - er det regeletikkens begrensninger som er tema. Det dreier seg om forskningsetikk og problemer knyttet til formalisering av forskerens etiske forpliktelser. Med utgangspunkt i et konkret eksempel peker Blok Johansen på hvordan forskere alltid må vurdere og revurdere situasjonen de befinner seg i, og at standardiserte, kontekstuavhengige prinsipper dermed aldri vil være tilstrekkelige. Blok Johansen argumenterer for at en prosedural forskningsetikk, forstått som forhåndsgitte retningslinjer, må suppleres med en kasuistisk forskningsetikk, forstått som en konkret og kontekstavhengig 
vurdering av etiske dilemmaer i praksis. Han foreslår Leibniz' etiske råd «dic hur hic» «si hvorfor du er her», forstått som «si hvorfor du gjør det du gjør» - som et feltrop som forskere bør benytte seg av i alle faser av sine prosjekter.

I den første artikkelen i åpen del holder vi oss i profesjonsetisk terreng. I «Fastlegers reservasjonsadgang - hyklersk eller velbegrunnet?» diskuterer Morten Magelssen og Gard O. Langeland debatten om fastlegers adgang til reservasjon mot henvisning til abort og påstanden om at et ønske om reservasjonsadgang er selvmotsigende og utilstrekkelig begrunnet. Med utgangspunkt i reservasjonslegenes foreslåtte balansegang - å nekte henvisning til abort, men i stedet legge til rette for at en kollega henviser - diskuteres mer generelt muligheter for å reservere seg mot bestemte sider ved profesjonsutøvelse satt opp mot påstander om hykleri og «de rene henders etikk». Forfatterne konkluderer med at reservasjonslegenes ønske ikke nødvendigvis er å betrakte som etisk inkonsistent. De tar imidlertid ikke opp andre viktige argumenter mot reservasjonsadgang, eksempelvis potensialet for opplevd krenkelse i møte med reservasjonslegen og pasientens rett til helsehjelp.

I nummerets siste artikkel - «Obligations of Poor Countries in Ensuring Global Justice: The Case of Uganda» - argumenterer John Barugahare og Reidar Lie for at fattige land må forplikte seg for at global rettferdighet skal bli mulig. Artikkelen er samtidig en kritikk av at diskursen om global rettferdighet oftest fokuserer på rike lands forpliktelse til å forbedre sosioøkonomiske kår i fattige land. Tre typer forpliktelser analyseres. Den første gjelder kravet om at fattige land må avstå fra aggressive handlinger for å muliggjøre global rettferdighet; ved å vise aggresjon mot andre staters autonomi og suverenitet bidrar fattige land til å opprettholde internasjonal urettferdighet. Dermed krenker de viktige rettigheter forankret i global rettferdighet. Det andre kravet dreier seg om myndighetenes forpliktelser til å sørge for at bistandshjelpen de mottar, kommer de trengende til gode. Et tredje viktig prinsipp gjelder fattige lands forpliktelse til å utøve «due diligence», det vil si selskapsgjennomgang, «tilbørlig flid». Forfatterne bruker Uganda som en hovedreferanse for å illustrere fattige lands forpliktelser i bestrebelsene på å oppnå global rettferdighet.

\section{Litteratur}

Grimen, H. (2006) «Profesjon og profesjonsmoral», Arbeidsnotat nr. 4, Senter for profesjonsstudier, Høgskolen i Oslo. Lastet ned 16. oktober 2014 fra http://www.hioa.no/Om-HiOA/SPS/ filer-sps/arbeidsnotater/4-2006-Grimen-profesjons-og-moral 